Article

\title{
Hydrothermal Liquefaction of Microalga Using Metal Oxide Catalyst
}

\author{
Alejandra Sánchez-Bayo ${ }^{1}{ }^{(0)}$, Rosalía Rodríguez ${ }^{1}$, Victoria Morales ${ }^{2}{ }^{(0}$, Nima Nasirian ${ }^{3}$, \\ Luis Fernando Bautista ${ }^{2}$ and Gemma Vicente ${ }^{1, *(\mathbb{D}}$ \\ 1 Department of Chemical, Energy and Mechanical Technology, Universidad Rey Juan Carlos, Móstoles, \\ 28933 Madrid, Spain; alejandra.sanchezbayo@urjc.es (A.S.-B.); rosalia.rodriguez@urjc.es (R.R.) \\ 2 Department of Chemical and Environmental Technology, Universidad Rey Juan Carlos, Móstoles, \\ 28933 Madrid, Spain; victoria.morales@urjc.es (V.M.); fernando.bautista@urjc.es (L.F.B.) \\ 3 Department of Agricultural Mechanisation and Biosystems Engineering, Shoushtar Branch, \\ Islamic Azad University, Daneshgah Blvd., Shoushtar 6451741117, Iran; n.nasirian@iau-shoushtar.ac.ir \\ * Correspondence: gemma.vicente@urjc.es
}

Received: 15 November 2019; Accepted: 17 December 2019; Published: 20 December 2019

check for updates

\begin{abstract}
The yield and composition of the biocrude obtained by hydrothermal liquefaction (HTL) of Nannocloropsis gaditana using heterogeneous catalysts were evaluated. The catalysts were based on metal oxides $\left(\mathrm{CaO}, \mathrm{CeO}_{2}, \mathrm{La}_{2} \mathrm{O}_{3}, \mathrm{MnO}_{2}\right.$, and $\left.\mathrm{Al}_{2} \mathrm{O}_{3}\right)$. The reactions were performed in a batch autoclave reactor at $320^{\circ} \mathrm{C}$ for $10 \mathrm{~min}$ with a $1: 10(\mathrm{wt} / \mathrm{wt})$ microalga:water ratio. These catalysts increased the yield of the liquefaction phase (from $94.14 \pm 0.30 \mathrm{wt} \%$ for $\mathrm{La}_{2} \mathrm{O}_{3}$ to $99.49 \pm 0.11 \mathrm{wt} \%$ for $\mathrm{MnO}_{2}$ ) as compared with the thermal reaction (92.60 $\left.\pm 1.20 \mathrm{wt} \%\right)$. Consequently, the biocrude yields also raised in the metal oxides catalysed HTL, showing values remarkably higher for the $\mathrm{CaO}(49.73 \pm 0.9 \mathrm{wt} \%)$ in comparison to the HTL without catalyst $(42.60 \pm 0.70 \mathrm{wt} \%)$. The $\mathrm{N}$ and $\mathrm{O}$ content of the biocrude obtained from non-catalytic HTL were $6.11 \pm 0.02 \mathrm{wt} \%$ and $10.50 \pm 0.50 \mathrm{wt} \%$, respectively. In this sense, the use of the metal oxides decreased the $\mathrm{N}$ content of the biocrude ( $4.62 \pm 0.15-5.45 \pm 0.11 \mathrm{wt} \%)$, although, they kept constant or increased its $\mathrm{O}$ content $(11.39 \pm 2.06-21.68 \pm 0.03 \mathrm{wt} \%)$. This study shows that $\mathrm{CaO}, \mathrm{CeO}_{2}$ and $\mathrm{Al}_{2} \mathrm{O}_{3}$ can be promising catalysts based on the remarkable amount of biocrude, the highest values of $\mathrm{C}, \mathrm{H}$, heating value, energy recovery, and the lowest content of $\mathrm{N}, \mathrm{O}$ and $\mathrm{S}$.
\end{abstract}

Keywords: microalgae; hydrothermal liquefaction; biocrude; metal-oxide catalyst

\section{Introduction}

Advanced biofuels derived from microalgae are considered a promising source of energy thanks to the well-known advantages of this type of biomass: high-production yields, neutral with respect to $\mathrm{CO}_{2}$ emissions, growing in industrial facilities and wastewater can be used as nutrients in the cultivation stage [1-4]. In this context, a thermochemical process such as the hydrothermal liquefaction (HTL) is postulated as one of the most promising current routes to produce biofuels from microalgae. HTL allows for the biofuel production from wet microalgae without a drying pre-treatment [5] and it tolerates the conversion of the whole microalga biomass, also including the low-lipid microalgal biomass which normally has higher growth rates [3,6-9]. Moderate temperatures $\left(200-380^{\circ} \mathrm{C}\right)$ and high pressures (10-25 MPa) and microalga:water ratios within the range $5 \%-15 \%$ are commonly used in HTL $[10,11]$. HTL yields a solid residue or biochar, a gaseous phase and two liquid fractions (aqueous and organic). Although all phases are useful in a microalga biorefinery, the organic liquid phase, usually referred to as biocrude or bio-oil, is the most interesting to produce biofuels [5]. 
The yield and quality of the biocrude is influenced by parameters such as temperature, pressure, reaction time and biomass:water ratio [12,13]. This biocrude obtained through HTL usually has a yield between 25 and $65 \mathrm{wt} \%$ under thermal conditions. However, it is characterised by having a high content of $\mathrm{N}$ and $\mathrm{O}$, since the initial microalga has a high content of these heteroatoms [14]. Consequently, the heating value is influenced in a negative way and the biocrudes obtained from HTL are not entirely in accordance with the regulations for their use as biofuel. For these reasons, current HTL research is focused mainly on improving the quality of the biocrude, reducing the content of these heteroatoms. The HTL biocrude can be upgraded with a conventional catalytic hydrotreatment [15], but novel processes involve the modification of the HTL process. Thus, some recent investigations deal to the HTL in two stages, where the $\mathrm{N}$ and $\mathrm{O}$ contained in the initial biomass is removed at low temperatures in a pre-treatment and the solid phase obtained in this first stage is transform to a low $\mathrm{N}$ and $\mathrm{O}$ content biocrude in the following HTL step $[6,16,17]$. Other authors have studied the use of co-solvents such as ethanol [18,19], obtaining high biocrude yields at lower temperatures. The use of appropriate catalysts in the HTL process is one of the most promising recent routes since the catalyst promotes dehydration, deoxygenation, denitrogenation and desulfurisation during the $\mathrm{HTL}$, consequently decreasing the $\mathrm{N}, \mathrm{O}$ and $\mathrm{S}$ content of the biocrude $[1,20]$. In particular, catalysts are capable of carrying out the hydrolysis of proteins, lipids and carbohydrates into smaller molecules, which in turn suffer decarboxylation and deamination reactions [20].

The homogeneous catalysts were the first used in HTL due to the ease of handling. Initially, catalytic tests used $\mathrm{Na}_{2} \mathrm{CO}_{3}$, obtaining positive effects on the biocrude yield. In addition, this catalyst allows for the reduction of the $\mathrm{N}$ and $\mathrm{O}$ present in the starting biomass, which increases the higher heating value $(\mathrm{HHV})$ of the biocrude and improves its quality [1,21]. However, its use can produce secondary reactions of saponification [22], which promoted the study of acid homogeneous catalysts, such as inorganic acid or short-chain organic acids, which act as hydrogenating agents of the process, reducing the biocrude $\mathrm{N}$ and $\mathrm{O}$ contents $[23,24]$. However, the homogenous catalyst cannot be reused in the catalytic HTL process.

The recovery ease of the heterogeneous catalysts makes the use of these catalysts in HTL a growing line of research. In this way, there are catalysts that promote the loss of $\mathrm{N}$ in biocrude, such as metals supported on carbon $(\mathrm{Pt} / \mathrm{C}, \mathrm{Ru} / \mathrm{C})$ or alumina with nickel or platinum $[10,20]$. Conversely, deoxygenation is promoted mainly by alumina doped with $\mathrm{Ni}$, Co or Mo [20]. In addition, new diverse materials (i.e., zeolites, carbon nanotubes, nanoparticles, etc.) have being tested recently to favour the loss of these heteroatoms in the biocrude $[25,26]$. In previous works, the content of $\mathrm{N}$ and $\mathrm{O}$ in the biocrude was reduced using heterogeneous catalysts such as $\mathrm{Pd}, \mathrm{Pt}$ or $\mathrm{Ru}$ supported on $\mathrm{C}, \mathrm{Co}, \mathrm{Mo}, \mathrm{Ni}$, $\mathrm{Pt}, \mathrm{Ni} / \mathrm{SiO}_{2}$ supported on $\mathrm{Al}_{2} \mathrm{O}_{3}$ and zeolites [27] and also metals supported in carbon nanotubes [25]. However, the possible contaminations and the activity of the materials need to be evaluated for its real reutilisation [3]. Therefore, the development of catalysts with a high hydrothermal stability that resist deactivation during HTL is essential.

In this context, the main objective of this work is to compare the biocrude obtained by the use of different metal oxide heterogeneous catalysts $\left(\mathrm{CaO}, \mathrm{CeO}_{2}, \mathrm{La}_{2} \mathrm{O}_{3}, \mathrm{MnO}_{2}\right.$ and $\left.\mathrm{Al}_{2} \mathrm{O}_{3}\right)$ in the HTL of Nannochloropsis gaditana to develop this process at an industrial scale. These catalysts have relatively low prices and have been highly used in the production of biodiesel thanks to their high basicity that promotes a greater catalytic activity to convert triglycerides without significant deactivation. In addition, metal oxides are non-soluble in the alcoholic media of this reaction and therefore, are recoverable [28-32]. However, there are no references about the use of oxides as catalysts in the microalga HTL process. These catalysts are advantageous for microalga HTL since their metal cations are Lewis acid sites that act as acceptors of electrons, whereas their oxygen anions are acceptors of protons or Bronze bases [33]. Besides, metal oxides are not soluble in the aqueous medium of the HTL process, so that the leaching reactions of the oxides are avoided, which would decrease their catalytic activity [30]. 


\section{Materials and Methods}

\subsection{Microalga}

The microalga used in this work was the N. gaditana, and it was supplied by AlgaEnergy S.A. (Madrid, Spain). Table 1 shows the biological composition (lipids, proteins, carbohydrates and ashes) together with the principal and minority elements composition of the microalgae, which were determined according to the methodology reported previously [34].

Table 1. Microalga composition (dry weight basis).

\begin{tabular}{cccccc}
\hline \multicolumn{2}{c}{ Biochemical Composition $\mathbf{( w t} \%)$} & \multicolumn{2}{c}{ Elemental Composition $\mathbf{( w t} \%)$} & \multicolumn{2}{c}{ Metals (mg/g) } \\
\hline Lipids & $35.52 \pm 1.23$ & $\mathrm{H}$ & $7.10 \pm 0.18$ & $\mathrm{Na}$ & $21.04 \pm 2.01$ \\
Proteins & $43.81 \pm 3.50$ & $\mathrm{C}$ & $48.7 \pm 0.14$ & $\mathrm{~K}$ & $3.53 \pm 0.09$ \\
Carbohydrates & $15.70 \pm 3.59$ & $\mathrm{~N}$ & $6.80 \pm 0.04$ & $\mathrm{Mg}$ & $0.90 \pm 0.03$ \\
Ashes & $4.50 \pm 0.79$ & $\mathrm{~S}$ & $0.90 \pm 0.04$ & $\mathrm{Fe}$ & $0.16 \pm 0.01$ \\
& & $\mathrm{O}$ & $36.5 \pm 0.20$ & $\mathrm{Ca}$ & $0.08 \pm 0.01$ \\
& & $\mathrm{P}$ & $6.43 \pm 0.02$ & & \\
\hline
\end{tabular}

\subsection{Catalysts}

The metal-oxide catalysts used in this work were calcium oxide $(\mathrm{CaO})$, cerium (IV) oxide $\left(\mathrm{CeO}_{2}\right)$, manganese (IV) orxide $\left(\mathrm{MnO}_{2}\right)$ and lanthanum (III) oxide $\left(\mathrm{La}_{2} \mathrm{O}_{3}\right)$ supplied by Sigma-Aldrich (St. Louis, MO, USA), and $\mathrm{Y}$-alumina $\left(\mathrm{Al}_{2} \mathrm{O}_{3}\right)$ provided by Alfa Aesar (Haverhill, MA, USA).

\subsection{Catalytic Liquefaction}

The catalytic liquefaction was performed in a $100 \mathrm{~mL}$ stainless-steel autoclave (EZ-SEAL ${ }^{\circledR}$, Autoclave Engineers. Erie, PA, USA). In each experiment, $33 \mathrm{~g}$ of slurry with a $10 \mathrm{wt} \%$ of microalga and $5 \mathrm{wt} \%$ metal-oxide catalyst was loaded into the reactor. A control thermal experiment was carried out in the absence of any catalyst for comparison purposes. All the experiments were run at $320{ }^{\circ} \mathrm{C}$ for $10 \mathrm{~min}$ in an inert atmosphere (nitrogen). The stirrer was set at $500 \mathrm{rpm}$ to ensure adequate mixing. At the end of the reaction, the autoclave was rapidly cooled down to room temperature to quench the reaction. Each HTL experiment was carried out three times for the statistical analysis.

When the reactor achieved room temperature, the gas phase was separated through the reactor valve that connects the reactor to the microGC Varian CP-4900 (Varian Inc., Palo Alto, CA, USA) where it was analysed. Then, $30 \mathrm{~mL}$ of dichloromethane (DCM) was used to collect the reaction mixture, which consists of solid residue, aqueous phase and biocrude. The solid residue and the catalyst were separated together by a vacuum filter, dried at $105^{\circ} \mathrm{C}$ for $24 \mathrm{~h}$ and weighted. The biocrude and aqueous phase were separated by decantation in a separation funnel. Both water and DCM were evaporated by vacuum evaporation from their respective fractions (aqueous phase and biocrude, respectively) in order to determine their yield and composition.

The yields (Y) of each phases were determined on a dry basis using Equations (1)-(4) [35] and the gas phase yield was calculated by the difference.

$$
\begin{gathered}
\mathrm{Y}_{\text {Biocrude }}(\%)=\frac{\text { mass of biocrude }}{\text { mass dry matter of microalgae }} \times 100 \\
\mathrm{Y}_{\text {Solid Residue }}(\%)=\frac{\text { mass of solid residue }}{\text { mass dry matter of microalgae }} \times 100 \\
\mathrm{Y}_{\text {Water-soluble products }}(\%)=\frac{\text { mass of water }- \text { soluble products }}{\text { mass dry matter of microalgae }} \times 100 \\
\text { Liquefaction phase }(\%)=\left(1-\frac{\text { mass of solid residue }}{\text { mass dry matter of microalgae }}\right) \times 100
\end{gathered}
$$




\subsection{Products Analysis}

\subsubsection{Biocrude Analysis}

The content of the principal elements (hydrogen, carbon, nitrogen, sulfur and oxygen) present in the biocrude oil were measured in a Vario EL III element analyser (Elementar Analysensysteme GmbH, Langenselbold, Germany) using sulphanilic acid as standard. With the content of these elements, the high heating value (HHV) of the bio-oil can be determined using the Boie equation (Equation (5)) [36].

$$
\mathrm{HHV}(\mathrm{MJ} / \mathrm{kg})=0.3516 \times \mathrm{C}+1.16225 \times \mathrm{H}-0.1109 \times \mathrm{O}+0.0628 \times \mathrm{N}
$$

The energy recovery (ER) was defined as the ratio of the total heating value of biocrude to the total heating value of microalgae, as shown by Equation (6).

$$
\operatorname{ER}(\%)=\frac{(\text { HHV of biocrude } \times \text { Mass of biocrude })}{(\text { HHV of microalga } \times \text { Mass of dry matter of microalgae })} \times 100
$$

The composition of biocrude was analysed by gas chromatography-mass spectrometry (GC-MS) (Bruker 450GC, Bruker Corp., Billerica, MA, USA). The samples were diluted with carbon disulphide and filtered with a $0.45 \mu \mathrm{m}$ nylon filter. The GC-MS was coupled to a triple quadrupole mass spectrometer (Bruker 320 MS, Bruker Corp., Billerica, MA, USA) that operates in electronic impact (EI) mode and it was provided with a Rxi-5Sil MS $30 \mathrm{~m} 0.25$ mm ID column (Restek, Lisses, France). Data acquisition and processing were performed by using Bruker MS Workstation software v.7. (Bruker Corp., Billerica, MA, USA).

\subsubsection{Analysis of Aqueous Phase}

The total organic content (TOC) was determined in a Shimadzu-V equipment (Shimadzu Corp., Kioto, Japan) while the $\mathrm{pH}$ was measured in a $\mathrm{pH}$ meter Basic $30 \mathrm{pH}$ meter (Crison Instruments, Barcelona, Spain). In addition, the water recovery from the aqueous phase was as evaluated by Equation (7).

$$
\text { Water recovery }(\%)=\frac{\text { mass of aqueous phase }}{\text { inital mass of water }} \times 100
$$

\subsubsection{Analysis of Gas Phase}

The catalytic hydrothermal liquefaction gas products were collected and analysed by using a gas chromatograph Varian CP-4900 (Varian Inc., Palo Alto, CA, USA) with a thermal conductivity detector (TCD) connected on-line to the autoclave reactor. The samples were analysed when the reaction mixture was cooled to $30^{\circ} \mathrm{C}$.

\subsubsection{Statistical Analysis}

Overall, data were subjected to statistical analysis by one-way analysis of variance (ANOVA), and Duncan's comparison of means using SPSS statistics software version 21 (IBM Corp., Armonk, NY, USA). Duncan's comparison of means tables were also applied to evaluate the effects of catalysts on the conversion yields and the elemental compositions of biocrude obtained through HTL of microalgae. Average and standard deviation of replications were also applied where required. In addition, before the analysis, the normality of data was approved by the Kolmogorov-Smirnov test. 


\section{Results and Discussion}

\subsection{Effects of Catalysts on the Yields of Hydrothermal Liquefaction (HTL) Processes}

The yields of the different fractions obtained from the catalytic HTL processes (biocrude, water-soluble products, gas phase and solid residue) are shown in Table 2 . The corresponding yields for the non-catalytic HTL (thermal) process are also included in the same table for comparison purposes.

Table 2. Effects of catalysts on the yields of hydrothermal liquefaction (HTL) process.

\begin{tabular}{|c|c|c|c|c|c|c|}
\hline & & Biocrude (wt $\%$ ) & $\mathrm{WSP}^{1}(\mathrm{wt} \%)$ & Gas (wt $\%)$ & $S R^{2}(w t \%)$ & $\mathrm{LP}^{3}\left(w \mathrm{t}^{\circ} \%\right)$ \\
\hline & Thermal & $42.60 \mathrm{~b}^{4}$ & $31.98 \mathrm{c}$ & $17.81 \mathrm{a}$ & $7.60 \mathrm{~d}$ & $92.69 \mathrm{~d}$ \\
\hline \multirow{5}{*}{ Catalysts } & $\mathrm{CaO}$ & $49.73 \mathrm{a}$ & $37.43 \mathrm{~b}$ & $7.57 \mathrm{~b}$ & $5.25 \mathrm{c}$ & $94.74 \mathrm{~cd}$ \\
\hline & $\mathrm{CeO}_{2}$ & $43.80 \mathrm{~b}$ & $44.12 \mathrm{a}$ & $9.82 \mathrm{~b}$ & $2.25 \mathrm{ab}$ & $97.74 \mathrm{ab}$ \\
\hline & $\mathrm{MnO}_{2}$ & $44.11 \mathrm{~b}$ & $37.61 \mathrm{~b}$ & $18.26 \mathrm{a}$ & $0.50 \mathrm{a}$ & $99.49 \mathrm{a}$ \\
\hline & $\mathrm{La}_{2} \mathrm{O}_{3}$ & $42.66 \mathrm{~b}$ & $38.98 \mathrm{~b}$ & $12.50 \mathrm{ab}$ & $5.85 \mathrm{~cd}$ & $94.14 \mathrm{~cd}$ \\
\hline & $\mathrm{Al}_{2} \mathrm{O}_{3}$ & $44.22 \mathrm{~b}$ & $34.02 \mathrm{c}$ & $17.44 \mathrm{a}$ & $4.30 \mathrm{bc}$ & $95.69 \mathrm{bc}$ \\
\hline
\end{tabular}

${ }^{1}$ Water-soluble products; ${ }^{2}$ Solid Residue; ${ }^{3}$ Liquefaction Phase; ${ }^{4}$ Different letters (a, b, c, and d) in the same column refers to statistical differences of Duncan's multiple range test at $p<0.05$ between control and different catalysts applied in the HTL process. "a" is the desirable mean value of groups for Biocrude, WSP, Gas, SR and LP.

The yield towards the fraction of greatest interest, i.e., biocrude, were mostly between 43 and $50 \mathrm{wt} \%$, which were near or somewhat higher than the equivalent obtained under thermal non-catalysed conditions (42.60 $\pm 0.80 \mathrm{wt} \%)$. According to Shi et al. [37], these catalysts prevent dehydration and promote the hydrolysis and cracking reactions. The use of $\mathrm{CeO}_{2}, \mathrm{MnO}_{2}, \mathrm{La}_{2} \mathrm{O}_{3}$ and $\mathrm{Al}_{2} \mathrm{O}_{3}$ as heterogeneous catalysts results in lower yields $(43.80 \pm 0.50 \mathrm{wt} \%, 44.11 \pm 0.50 \mathrm{wt} \%, 42.66 \pm 1.10 \mathrm{wt} \%$ and $44.22 \pm 1.60 \mathrm{wt} \%$, respectively) than the use of $\mathrm{CaO}(49.73 \pm 0.90 \mathrm{wt} \%)$. If we attend at the electronegativity of these catalysts under the reaction conditions, the first four had a electronegativity between 8 and 11.5 while $\mathrm{CaO}$ had a value close to 5 [38]. Consequently, the highest yield of biocrude was obtained with the most basic oxide catalyst $(\mathrm{CaO})$, which promoted the hydrolysis and cracking reactions. In addition, the basicity of $\mathrm{CaO}$ could give rise to secondary reactions of saponification, decreasing the biocrude yield [22]. However, the saponification reactions were not significant at the short reaction time used in this work (10 $\mathrm{min})$ in comparison to the longer reaction times $(60 \mathrm{~min})$ in a previous study using palm biomass as raw material [38].

The yields of the water-soluble products for basic metal oxides catalysts $\left(\mathrm{CaO}, \mathrm{CeO}_{2}, \mathrm{MnO}_{2}\right.$, $\mathrm{La}_{2} \mathrm{O}_{3}$ ) ranged from $37.43 \pm 0.61 \mathrm{wt} \%$ to $44.12 \pm 0.92 \mathrm{wt} \%$, being higher than the corresponding value in the thermal HTL $(31.98 \pm 1.20 \mathrm{wt} \%)$. This implies that the metallic oxides also promote an increase of this fraction yield, which was also previously observed in the HTL of rice husk using these types of catalysts [37]. In addition, the acid nature of these types of catalysts has an influence on the yield of the water-soluble products. Thus, the more acidic $\mathrm{Al}_{2} \mathrm{O}_{3}$ had a lower yield of water-soluble compounds than the more basic metal oxides.

The yields of the gas fraction obtained with $\mathrm{CaO}$ and $\mathrm{CeO}_{2}$ were significantly lower $(7.57 \pm 0.50 \mathrm{wt} \%$ and $9.82 \pm 0.01 \mathrm{wt} \%$, respectively) than the thermal HTL $(17.81 \pm 2.27 \mathrm{wt} \%)$, whereas the yield of this fraction using $\mathrm{La}_{2} \mathrm{O}_{3}(12.50 \pm 1.90 \mathrm{wt} \%), \mathrm{MnO}_{2}(18.27 \pm 1.41 \mathrm{wt} \%)$ and $\mathrm{Al}_{2} \mathrm{O}_{3}$ $(17.44 \pm 3.21 \mathrm{wt} \%)$ was statistically the same as the one obtained without a catalyst. The decrease of the gas fraction yield could be related to the observed increase of the biocrude and water-soluble product yields because of the interaction between the different phases during HTL, according to the kinetic model proposed by Valdez [39].

The liquefied fraction yields obtained with metallic oxides were generally higher than this fraction yield obtained in the HTL without catalyst (the liquefaction phase values of $\mathrm{MnO}_{2}, \mathrm{CeO}_{2}$ and $\mathrm{Al}_{2} \mathrm{O}_{3}$ were significantly higher than the value of the non-catalysed HTL), which is due to the detected increase in the yields of the liquid fractions (water-soluble products and biocrude) with these catalysts. These yields are in all cases higher than $94 \mathrm{wt} \%$, even reaching $99.49 \pm 0.70 \mathrm{wt} \%$ when $\mathrm{MnO}_{2}$ was used. It is noteworthy, therefore, that the high yield of the liquefied fraction indicates a conversion of the 
microalga near $100 \%$. These high yields are linked to the low amounts of solid residue obtained in the catalytic processes $(0.50 \mathrm{wt} \%$ to just under $6 \mathrm{wt} \%)$ in comparison with the solid yield in the thermal reaction $(7.60 \pm 0.70 \mathrm{wt} \%)$. This increase in the liquefied fraction and a low yield of the solid residue was observed previously in the HTL of rice husk and microalga Nannochloropsis with the same type of catalysts $[37,40]$.

\subsection{Element Content, Higher Heating Value (HHV) and Energy Recovery (ER) of Obtained Biocrude}

Table 3 shows the elemental analysis, HHV and energy recovery (ER) of the biocrudes obtained with the metal oxide-catalysed HTL and the non-catalysed process.

Biocrudes obtained with the metal oxides $\mathrm{CaO}, \mathrm{CeO}_{2}$ and $\mathrm{La}_{2} \mathrm{O}_{3}$ had statistically similar $\mathrm{N}$ content $(4.76 \pm 0.02 \mathrm{wt} \%, 4.62 \pm 0.15 \mathrm{wt} \%$ and $4.64 \pm 0.01 \mathrm{wt} \%$, respectively). Therefore, these catalysts are suitable to carry out denitrogenation reactions. However, the $\mathrm{N}$ content of the biocrude obtained with $\mathrm{MnO}_{2}$ and $\mathrm{Al}_{2} \mathrm{O}_{3}$ were slightly higher $(5.45 \pm 0.11 \mathrm{wt} \%$ and $5.39 \pm 0.21 \mathrm{wt} \%)$. In all cases, a significant decrease was observed in the $\mathrm{N}$ content with respect to the non-catalysed reaction $(6.11 \pm 0.02 \mathrm{wt} \%)$. This fact corroborates the power of metal oxides as catalysts of hydrolysis and cracking reactions breaking the macromolecules (proteins and lipids) to give compounds with $\mathrm{N}$ soluble in the aqueous phase fraction that decrease the content of this heteroatom in biocrude [20,38].

Table 3. Elemental composition, higher heating value (HHV) and energy recovery (ER) of the biocrude obtained through HTL of microalgae with different catalysts compared to non-catalysed reaction.

\begin{tabular}{|c|c|c|c|c|c|c|c|c|}
\hline & & N (wt\%) & $\mathrm{C}(\mathrm{wt} \%)$ & $H(w t \%)$ & $\mathrm{S}\left(w t^{\circ} \%\right)$ & $\mathrm{O}(w t \%)$ & HHV (MJ/kg) & ER (\%) \\
\hline & Thermal & $6.11 \mathrm{c}$ & $73.84 \mathrm{a}^{1}$ & $9.17 \mathrm{c}$ & $0.31 \mathrm{c}$ & $10.54 \mathrm{a}$ & $33.18 \mathrm{a}$ & $58.25 \mathrm{a}$ \\
\hline \multirow{5}{*}{ Catalyst } & $\mathrm{CaO}$ & $4.76 \mathrm{a}$ & $69.98 \mathrm{~b}$ & $9.31 \mathrm{c}$ & $0.40 \mathrm{~d}$ & $15.59 \mathrm{~b}$ & $31.47 \mathrm{~b}$ & $55.00 \mathrm{~b}$ \\
\hline & $\mathrm{CeO}_{2}$ & $4.62 \mathrm{a}$ & $73.04 \mathrm{a}$ & $9.83 \mathrm{a}$ & $0.16 \mathrm{a}$ & $12.32 \mathrm{a}$ & $33.40 \mathrm{a}$ & $58.50 \mathrm{a}$ \\
\hline & $\mathrm{MnO}_{2}$ & $5.45 \mathrm{~b}$ & $70.17 \mathrm{~b}$ & $9.17 \mathrm{c}$ & $0.16 \mathrm{a}$ & $14.94 \mathrm{~b}$ & $31.49 \mathrm{~b}$ & $55.25 \mathrm{~b}$ \\
\hline & $\mathrm{La}_{2} \mathrm{O}_{3}$ & $4.63 \mathrm{a}$ & $64.88 \mathrm{c}$ & $8.39 \mathrm{~d}$ & $0.39 \mathrm{~d}$ & $21.68 c$ & $30.12 \mathrm{c}$ & $53.00 \mathrm{c}$ \\
\hline & $\mathrm{Al}_{2} \mathrm{O}_{3}$ & $5.39 \mathrm{~b}$ & $73.36 \mathrm{a}$ & $9.64 \mathrm{~b}$ & $0.20 \mathrm{~b}$ & $11.39 \mathrm{a}$ & $33.43 \mathrm{a}$ & $58.75 \mathrm{a}$ \\
\hline
\end{tabular}

${ }^{1}$ Different letters (a, b, c, and d) in the same column refers to statistical differences of Duncan's multiple range test at $p<0.05$ between control and different catalysts applied in the HTL process. "a" is the desirable mean value of groups for $\mathrm{C}, \mathrm{H}, \mathrm{HHV}, \mathrm{ER}, \mathrm{N}, \mathrm{O}$ and $\mathrm{S}$.

Regarding the $\mathrm{O}$ concentration in the biocrudes, the values obtained with the metal oxides ranged from $14.94 \pm 0.58 \mathrm{wt} \%$ for $\mathrm{MnO}_{2}$ to $21.68 \pm 0.04 \mathrm{wt} \%$ for $\mathrm{La}_{2} \mathrm{O}_{3}$, being higher than those obtained by the thermal reaction $(10.54 \pm 0.50 \mathrm{wt} \%)$. This fact may be due to the hydrolysis of the main molecules (carbohydrates, lipids and proteins) into smaller ones that cannot undergo deoxygenation. However, the $\mathrm{O}$ content could be improved with these catalysts at a longer reaction time [20]. In spite of that, in comparison with thermal reaction, no considerable growth was detected in the O concentration for $\mathrm{CeO}_{2}$ and $\mathrm{Al}_{2} \mathrm{O}_{3}$ catalysts.

The HHV values obtained from the elemental analysis were between $30.12 \pm 0.01$ and $33.43 \pm 0.91 \mathrm{MJ} / \mathrm{kg}$ (Table 2), regardless of the type of metallic oxide used. These values are typical of biocrudes obtained from microalgae by HTL process (30-43 MJ/kg) [20]. Conversely, the ER were between $52.88 \% \pm 0.02 \%$ to $58.75 \% \pm 1.62 \%$. The $\mathrm{HHV}$ and ER results of the $\mathrm{CeO}_{2}$ and $\mathrm{Al}_{2} \mathrm{O}_{3}$ were similar to those of the thermal reaction and the mentioned indexes for $\mathrm{CaO}$ and $\mathrm{MnO}_{2}$ were slightly lower. These values were approximately similar to the ones reported previously for fast HTL $\left(400{ }^{\circ} \mathrm{C}\right.$, $2 \mathrm{~min}$ ) with $\mathrm{Pd} / \mathrm{C}, \mathrm{Pt} / \mathrm{C}$ or dimethalic alumina catalysts [15], but somewhat lower than those obtained in the HTL at $350{ }^{\circ} \mathrm{C}$ and $60 \mathrm{~min}$ with similar catalysts [27]. Among the catalysts applied in this study, $\mathrm{CeO}_{2}$ resulted in remarkable specifications for the obtained biocrude through HTL of microalgae, N. gaditana. As can be clearly seen in Table 2, the highest values of $\mathrm{C}$ and $\mathrm{H}$ content, $\mathrm{HHV}$ and ER, in addition to the lowest content of $\mathrm{N}, \mathrm{O}$ and $\mathrm{S}$ occurred as a consequence of the HTL process using the $\mathrm{CeO}_{2}$ catalyst. 
Because the biocrude properties are highly dependent on the $\mathrm{H} / \mathrm{C}, \mathrm{N} / \mathrm{C}$ and $\mathrm{O} / \mathrm{C}$ atomic ratios, these were calculated and compared with the corresponding ratios of the thermal biocrude and the initial microalgal biomass. In addition, the atomic ratios of the biocrudes were compared with a biodiesel obtained from rapeseed oil that complies European Biodiesel EN 14214 Standards, a biodiesel from $N$. gaditana oil that meets the biodiesel specifications except for the content of polyunsaturated ( $\geq 4$ double bonds) methylester and a reference fossil diesel complying European Standard EN-590. The atomic ratios were represented using a Van Krevelen diagram (Figure $1 \mathrm{a}, \mathrm{b}$ ). The H/C, N/C and O/C ratio for the reference diesel were $1.84,0.005$ and 0.008 , respectively. In the HTL process, deoxygenation and denitrogenation mechanisms are produced during the reaction [12]. Therefore, $\mathrm{O} / \mathrm{C}$ and N/C ratios decrease with respect to the initial biomass around $80 \%$ and $40 \%$, respectively. The $\mathrm{H} / \mathrm{C}$ ratios shown in Figure 1 were similar for the five biocrudes regardless of the catalysts used, showing values around $1.50-1.65$. However, the ratio of the thermal biocrude obtained was 1.25 because of its higher percentage of $C$ in the composition. On the other hand, the N/C ratios were all between 0.05 and 0.06 , slightly higher than that for the reference diesel oil (0.005) and somewhat lower than the thermal biocrude (0.084). Despite the fact that the $\mathrm{N}$ content was reduced with respect to the thermal reaction, a total recovery of $C$ in the biocrude was not achieved and therefore, the N/C ratio obtained was somewhat higher than the limits reported in the literature [20]. The values of $\mathrm{O} / \mathrm{C}$ were between 0.10 and 0.20 , which were higher values than the ones obtained previously for this heterogeneous catalysed process (0.004-0.053) [15], which is associated to the fact that the $\mathrm{O}$ and $\mathrm{C}$ were not completely recovered in the biocrude phase. However, the $\mathrm{O} / \mathrm{C}$ ratios obtained with oxygenated biofuels, such as biodiesels from rapeseed and $N$. gaditana oils, were close to 0.10 and similar to the $\mathrm{O} / \mathrm{C}$ ratios of the biocrudes obtained using $\mathrm{CeO}_{2}(0.135)$ and $\mathrm{Al}_{2} \mathrm{O}_{3}$ (0.113). Longer reaction times are required to decrease the $\mathrm{O}$ concentrations of the biocrude obtained by HTL with heterogeneous catalysts. In spite of higher values of the $\mathrm{H} / \mathrm{C}, \mathrm{N} / \mathrm{C}$ and $\mathrm{O} / \mathrm{C}$, we can also remark on the fact that, apart from higher $\mathrm{NO}_{\mathrm{x}}$ emission due to the higher $\mathrm{N}$ content and lower heating value, using oxygenated biofuels such as biodiesel and bioethanol has significantly reduced the formation of air pollutants like $\mathrm{CO}$, soot and unburned hydrocarbons and increased the combustion efficiency. In addition, developing engine technologies and fuel additives, besides optimizing biocrude production and upgrading systems, will provide a sustainable source of biofuel for commercial purposes [41-44].

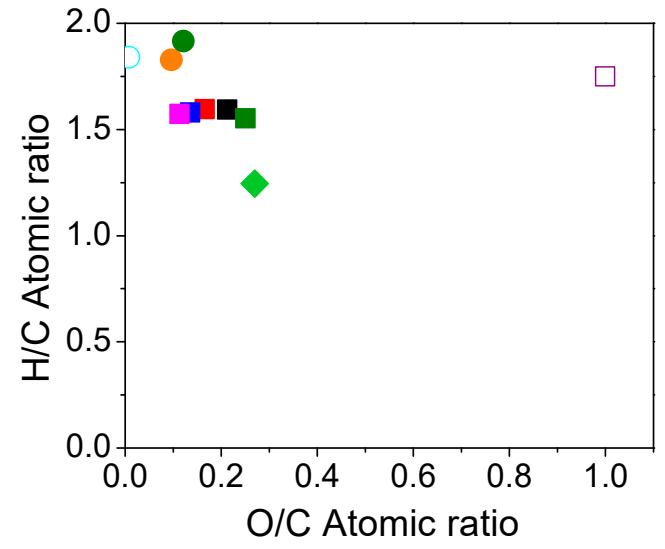

(a)

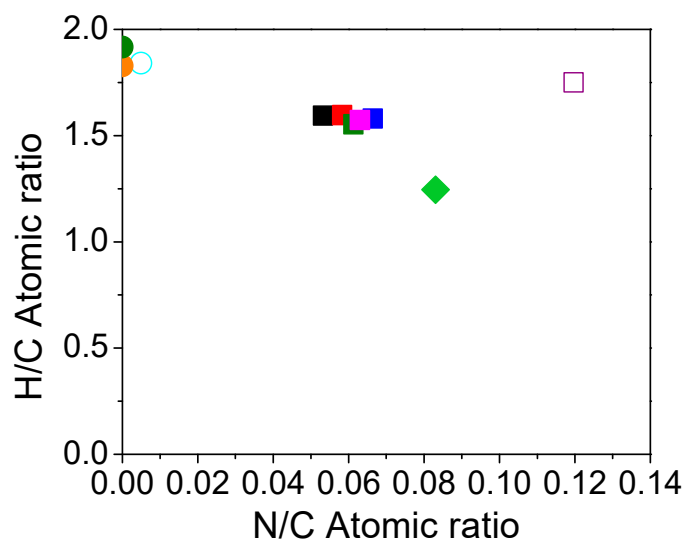

(b)

Figure 1. Van Krevelen diagram for biocrude obtained with metal oxide catalyst ( $\mathbf{\square}) \mathrm{CaO},(\square) \mathrm{CeO}_{2},(\square)$ $\mathrm{MnO}_{2},(\square) \mathrm{La}_{2} \mathrm{O}_{3}$ and $(\square) \mathrm{Al}_{2} \mathrm{O}_{3}$. For comparison purposes, thermal conditions ( () , reference diesel $(\bigcirc)$, biodiesel from rapeseed oil (๑), biodiesel from N. gaditana oil (๑) and microalga N. gaditana $(\square)$ are shown. (a) O/C vs H/C and (b) N/C vs H/C).

The composition of the biocrudes obtained by GC-MS, grouped by families, is shown in Table 4 . A high content of acids was obtained in the biocrudes using $\mathrm{CaO}, \mathrm{CeO}_{2}, \mathrm{La}_{2} \mathrm{O}_{3}$ and $\mathrm{Al}_{2} \mathrm{O}_{3}$, achieving 
values of $28.08 w \mathrm{t} \%, 31.18 w \mathrm{w} \%, 24.99 w \mathrm{t} \%$ and $17.82 \mathrm{wt} \%$, respectively. These catalysts promote hydrolysis reactions to a greater extent, increasing the amount of organic acids and alcohols. The latter achieved values of 9.46-18.48 wt\%. Conversely, the content of organic acids in the biocrude obtained in the HTL with $\mathrm{MnO}_{2}$ was remarkably higher (60.96 wt\%). In this sense, this catalyst promotes the deamination reactions of aminoacids to organic acids, in addition to the hydrolysis of lipids to these organic acids. The high content of oxygenates (mainly acids, alcohols and amides) was around 65-70 wt\% of the composition, which causes a low biocrude stability, a low HHV and high corrosive power [45]. However, these values were lower than those of the thermal reaction were, where the oxygenated compounds were higher than $85 \mathrm{wt} \%$. Attending to the $\mathrm{N}$ compounds (amines, amides and nitriles), they supposed between a $20.24 \mathrm{wt} \%$ and a $36.85 \mathrm{wt} \%$. These compounds mainly come from the hydrolysis of the proteins [12]. The content of amines was higher than that of the thermal reaction $(9.74 \mathrm{wt} \%)$, while the amides were lower than the one obtained in the control thermal reaction (31.26 wt $\%)$. Finally, the amount of hydrocarbons in the biocrudes obtained with these metal oxides were higher (12.71-15.36 $\mathrm{wt} \%$ ) than the corresponding value obtained in the thermal control HTL $(6.02 \mathrm{wt} \%)$, that is associated again with the decrease of heteroatoms in biocrude.

Table 4. Biocrudes composition determinate by gas chromatography-mass spectrometry (GC-MS).

\begin{tabular}{|c|c|c|c|c|c|c|c|c|c|c|c|}
\hline & & \multicolumn{10}{|c|}{ Composition (\%) } \\
\hline & & Acid & Alcohol & Aldehyde & Amine & Amide & Ketone & $\mathrm{HC}$ & AHC & Ether & Nitrile \\
\hline & Thermal & 43.25 & 6.49 & 0.46 & 9.74 & 31.26 & 1.99 & 3.71 & 2.31 & 0.55 & 0.23 \\
\hline \multirow{5}{*}{ Catalyst } & $\mathrm{CaO}$ & 28.09 & 18.48 & 0.00 & 16.51 & 10.10 & 7.31 & 11.26 & 4.10 & n.d & 3.11 \\
\hline & $\mathrm{CeO}_{2}$ & 31.18 & 9.46 & 0.00 & 18.84 & 16.30 & 9.44 & 12.51 & 0.33 & n.d & 1.71 \\
\hline & $\mathrm{MnO}_{2}$ & 60.96 & 0.00 & 0.00 & 10.71 & 6.08 & 9.41 & 10.68 & 2.03 & n.d & 0.12 \\
\hline & $\mathrm{La}_{2} \mathrm{O}_{3}$ & 24.99 & 17.32 & 0.00 & 15.12 & 9.36 & 16.53 & 13.26 & 0.00 & n.d & 3.13 \\
\hline & $\mathrm{Al}_{2} \mathrm{O}_{3}$ & 17.82 & 17.27 & 0.00 & 12.02 & 34.78 & 8.31 & 7.10 & 1.81 & n.d & 0.14 \\
\hline
\end{tabular}

HC: Hydrocarbon; AHC: Aromatic hydrocarbon; n.d: non-detectable.

The boiling temperature of the biocrudes obtained by metal oxide catalysis was determined and compared with a diesel that complies with the EN-590 standard (Table 5). The results obtained for the boiling point showed that the obtained biocrudes boiled completely at temperatures close to $529.20-551.80^{\circ} \mathrm{C}$ and were similar to the one achieved in the thermal reaction $\left(546.00^{\circ} \mathrm{C}\right)$. However, these boiling points of the biocrude were higher than in the reference diesel $\left(476.10^{\circ} \mathrm{C}\right)$. Despite the decrease in the heteroatom content of the biocrudes obtained with the catalysts, the content of $\mathrm{N}$ and $\mathrm{O}$ remained high compared to the diesel that follows the regulations. This implies that the biocrude containing these electronegative heteroatoms is capable of forming more intense dipole-dipole interactions, which would lead to a higher apparent boiling point in the mixture. This fact was previously observed in the metal oxide-catalysed HTL of Malaysian oil palm biomass [38] due to the presence of oxygenated compounds and aromatic compounds.

Table 5. Boiling point distribution of biocrudes obtained from HTL of microalgae using metal oxides catalysts compared with reference diesel.

\begin{tabular}{ccccccc}
\hline & \multicolumn{5}{c}{ Boiling Point $\left({ }^{\circ} \mathbf{C}\right)$} \\
\cline { 2 - 7 } & Distillation (\%) & $\mathbf{2 0}$ & $\mathbf{4 0}$ & $\mathbf{6 0}$ & $\mathbf{8 0}$ & $\mathbf{1 0 0}$ \\
\hline \multirow{5}{*}{ Catalyst } & Reference diesel & 223.40 & 290.10 & 332.90 & 379.70 & 476.10 \\
\cline { 2 - 7 } & Thermal & 417.80 & 422.50 & 438.90 & 476.30 & 545.60 \\
\hline & $\mathrm{CaO}$ & 330.90 & 395.20 & 439.30 & 486.00 & 539.50 \\
& $\mathrm{CeO}_{2}$ & 348.70 & 393.50 & 420.10 & 467.10 & 529.20 \\
& $\mathrm{MnO}_{2}$ & 319.80 & 388.50 & 418.10 & 467.90 & 539.20 \\
& $\mathrm{La}_{2} \mathrm{O}_{3}$ & 301.90 & 383.00 & 418.30 & 480.60 & 546.20 \\
& $\mathrm{Al}_{2} \mathrm{O}_{3}$ & 347.70 & 395.20 & 436.00 & 488.00 & 551.80 \\
\hline
\end{tabular}




\subsection{Analysis of Aqueous Phase}

Although no statistically significant differences have been observed by one-way ANOVA, the recovery of the aqueous phases obtained in the reactions of HTL catalysed by metal oxides was slightly higher $(92.11 \pm 1.10-95.48 \pm 2.07 \mathrm{wt} \%)$ than the recovery of this fraction in the thermal process $(90.13 \pm 1.11 \mathrm{wt} \%)$ (Table 6). The $\mathrm{pH}$ of this phase (8.20-10.80) is marked by the basicity of the catalyst. The values of the different fractions according to the used catalyst have coherence in function of the basicity of the catalysts used, the lowest value being for the $\mathrm{Al}_{2} \mathrm{O}_{3}$ and the highest for the oxide of greater basic character, the $\mathrm{CaO}[38]$.

Table 6. Characteristics of the aqueous phase.

\begin{tabular}{ccccc}
\hline & Water Recovery $(\mathbf{w t} \%)$ & $\mathbf{p H}$ & TOC (mg/L) \\
\hline \multirow{6}{*}{ Catalysts } & Thermal & $90 \pm 1$ & 8.40 & $1283 \pm 4$ \\
& $\mathrm{CaO}$ & $93 \pm 1$ & 10.80 & $745 \pm 1$ \\
& $\mathrm{CeO}_{2}$ & $94 \pm 2$ & 8.53 & $698 \pm 2$ \\
& $\mathrm{MnO}_{2}$ & $92 \pm 1$ & 8.70 & $694 \pm 1$ \\
& $\mathrm{La}_{2} \mathrm{O}_{3}$ & $94 \pm 1$ & 8.90 & $681 \pm 2$ \\
$\mathrm{Al}_{2} \mathrm{O}_{3}$ & $95 \pm 2$ & 8.20 & $741 \pm 5$ \\
\hline
\end{tabular}

TOC: Total Organic Carbon.

The total organic carbon (TOC) values (681-745 ppm) indicated a high formation of new organic compounds soluble in aqueous medium. These values are within the ranges found in the starting biomass at temperatures between 300 and $350{ }^{\circ} \mathrm{C}(300-1146$ ppm) [23]. However, the value obtained in the thermal reaction was higher (1283 ppm). Therefore, the carbon content was lower in the aqueous fraction obtained through metal oxide-catalysed HTL in comparison to the thermal reaction, which implies the existence of other elements such as $\mathrm{N}$ or $\mathrm{O}$. As previously mentioned, the use of metal oxides as catalysts reduced the presence of this $\mathrm{N}$ in the biocrude, increasing the amount of this heteroatom in the aqueous phase.

\subsection{Analysis of Gas Phase}

The gaseous phases obtained by metal oxide heterogeneous catalysis had a composition similar to that obtained in the thermal reaction. These fractions were composed mainly of $\mathrm{CO}_{2}$, by more than $95 \%$ in all cases. The gas fraction also contained small amounts of saturated and monounsatured linear light hydrocarbons $\left(\mathrm{C}_{1}-\mathrm{C}_{4}\right)(<1 \%)$, and less than $1 \%$ of $\mathrm{H}_{2}$ and $\mathrm{CO}$. Therefore, the results showed that, despite the different catalysts used in the HTL reactions, the composition was always similar to the previous results in the literature $[27,38]$. The high and low contents of $\mathrm{CO}_{2}$ and light hydrocarbons respectively, were related to the working temperature, which was below the critical point of water. In addition, the low concentration of $\mathrm{CO}$ can be due to the fact that the elimination of hydrogen occurred mainly by decarboxylation instead of decarbonylation [46]. Taking into account the $\mathrm{CO}_{2}$-rich gas fraction obtained in all cases, this fraction can be integrated into a microalgal biorefinery, with the growth of the microalga stage being recirculated, thus providing the carbon source necessary for its development.

\section{Conclusions}

Our results indicated that metal oxide catalysts can improve the results of the HTL process of microalgae in comparison with the non-catalysed reaction. The catalytic HTL catalysts increased the yields of biocrude $(42.60 \pm 0.80-49.73 \pm 0.90 \mathrm{wt} \%)$ compaed to the thermal reaction $(42.60 \pm 0.02 \mathrm{wt} \%)$. The biocrude yield was remarkably high with the $\mathrm{CaO}$ catalyst $(49.73 \pm 0.90 \mathrm{wt} \%)$. In addition, the biocrude yields increase for $\mathrm{CeO}_{2}(43.80 \pm 0.50 \mathrm{wt} \%), \mathrm{Al}_{2} \mathrm{O}_{3}(44.22 \pm 1.60 \mathrm{wt} \%)$ and $\mathrm{MnO}_{2}$ $(44.11 \pm 0.60 \mathrm{wt} \%)$ were also high. Biocrudes showed a decrease in the $\mathrm{N}$ content with all the metal oxides compared to the one obtained without the catalyst $(6.11 \pm 0.0 .02 \mathrm{wt} \%)$. The $\mathrm{N}$ content achieved 
with $\mathrm{CeO}_{2}, \mathrm{La}_{2} \mathrm{O}_{3}$ and $\mathrm{CaO}$ was low $(4.63 \pm 0.15 \mathrm{wt} \%, 4.64 \pm 0.01 \mathrm{wt} \%$ and $4.76 \pm 0.02 \mathrm{wt} \%$, respectively). However, despite being reduced in comparison to microalgae (36.50 $\pm 0.20 \mathrm{wt} \%)$, there is still a high content of $\mathrm{O}$ in all the biocrudes $(11.39 \pm 2.06-21.68 \pm 0.03 \mathrm{wt} \%)$. Thus, apart from the positive effects of catalysts utilizing on $\mathrm{HTL}$ process, $\mathrm{CeO}_{2}$, along with $\mathrm{Al}_{2} \mathrm{O}_{3}$ and $\mathrm{CaO}$, can be considered for further investigations to achieve the greatest yield of produced biocrude with optimised specifications.

Author Contributions: A.S.-B. performed the experimental work (catalytic experiments and sample characterisation). L.F.B. and G.V. devised the experimental work. R.R. and V.M. helped in the revision of the HTL results. N.N. performed the statistical analysis. A.S.-B., G.V. and N.N. wrote the final version of the manuscript. All authors have read and agreed to the published version of the manuscript.

Funding: The authors gratefully acknowledge the financial support from Comunidad de Madrid provided through project ALGATEC-CM (P2018/BAA-4532), co-financed by the European Social Fund and the European Regional Development Fund, and the BIOHIDROALGA project (ENE2017-83696-R), financed by Ministerio de Economía y Competitividad of Spain.

Conflicts of Interest: The authors declare no conflict of interest.

\section{References}

1. Biller, P.; Riley, R.; Ross, A.B. Catalytic hydrothermal processing of microalgae: Decomposition and upgrading of lipids. Bioresour. Technol. 2011, 102, 4841-4848. [CrossRef] [PubMed]

2. Huang, Y.; Chen, Y.; Xie, J.; Liu, H.; Yin, X.; Wu, C. Bio-oil production from hydrothermal liquefaction of high-protein high-ash microalgae including wild Cyanobacteria sp. and cultivated Bacillariophyta sp. Fuel 2016, 183, 9-19. [CrossRef]

3. López Barreiro, D.; Prins, W.; Ronsse, F.; Brilman, W. Hydrothermal liquefaction (HTL) of microalgae for biofuel production: State of the art review and future prospects. Biomass Bioenergy 2013, 53, $113-127$. [CrossRef]

4. López Barreiro, D.; Zamalloa, C.; Boon, N.; Vyverman, W.; Ronsse, F.; Brilman, W.; Prins, W. Influence of strain-specific parameters on hydrothermal liquefaction of microalgae. Bioresour. Technol. 2013, 146, 463-471. [CrossRef]

5. Tian, C.; Li, B.; Liu, Z.; Zhang, Y.; Lu, H. Hydrothermal liquefaction for algal biorefinery: A critical review. Renew. Sustain. Energy Rev. 2014, 38, 933-950. [CrossRef]

6. Jazrawi, C.; Biller, P.; He, Y.; Montoya, A.; Ross, A.B.; Maschmeyer, T.; Haynes, B.S. Two-stage hydrothermal liquefaction of a high-protein microalga. Algal Res. 2015, 8, 15-22. [CrossRef]

7. Jena, U.; Das, K.C.C.; Kastner, J.R.R. Effect of operating conditions of thermochemical liquefaction on biocrude production from Spirulina platensis. Bioresour. Technol. 2011, 102, 6221-6229. [CrossRef]

8. Tang, X.; Zhang, C.; Li, Z.; Yang, X. Element and chemical compounds transfer in bio-crude from hydrothermal liquefaction of microalgae. Bioresour. Technol. 2015, 202, 8-14. [CrossRef]

9. Toor, S.S.; Rosendahl, L.; Rudolf, A. Hydrothermal liquefaction of biomass: A review of subcritical water technologies. Energy 2011, 36, 2328-2342. [CrossRef]

10. Galadima, A.; Muraza, O. Hydrothermal liquefaction of algae and bio-oil upgrading into liquid fuels: Role of heterogeneous catalysts. Renew. Sustain. Energy Rev. 2018, 81, 1037-1048. [CrossRef]

11. Jarvis, J.M.; Billing, J.M.; Hallen, R.T.; Schmidt, A.J.; Schaub, T.M. Hydrothermal Liquefaction Biocrude Compositions Compared to Petroleum Crude and Shale Oil. Energy Fuels 2017, 31, 2896-2906. [CrossRef]

12. Gollakota, A.R.K.; Kishore, N.; Gu, S. A review on hydrothermal liquefaction of biomass. Renew. Sustain. Energy Rev. 2018, 81, 1378-1392. [CrossRef]

13. Mathimani, T.; Mallick, N. A review on the hydrothermal processing of microalgal biomass to bio-oil Knowledge gaps and recent advances. J. Clean. Prod. 2019, 217, 69-84. [CrossRef]

14. Chen, W.-H.; Lin, B.-J.; Huang, M.-Y.; Chang, J.-S. Thermochemical conversion of microalgal biomass into biofuels: A review. Bioresour. Technol. 2014, 184, 314-327. [CrossRef]

15. Patel, B.; Arcelus-Arrillaga, P.; Izadpanah, A.; Hellgardt, K. Catalytic Hydrotreatment of algal biocrude from fast Hydrothermal Liquefaction. Renew. Energy 2017, 101, 1094-1101. [CrossRef]

16. Montero-Hidalgo, M.; Espada, J.J.; Rodríguez, R.; Morales, V.; Bautista, L.F.; Vicente, G. Mild Hydrothermal Pretreatment of Microalgae for the Production of Biocrude with a Low N and O Content. Processes 2019, 7, 630. [CrossRef] 
17. Prapaiwatcharapan, K.; Sunphorka, S.; Kuchonthara, P.; Kangvansaichol, K.; Hinchiranan, N. Single- and two-step hydrothermal liquefaction of microalgae in a semi-continuous reactor: Effect of the operating parameters. Bioresour. Technol. 2015, 191, 426-432. [CrossRef]

18. Chen, Y.; Wu, Y.; Zhang, P.; Hua, D.; Yang, M.; Li, C.; Chen, Z.; Liu, J. Direct liquefaction of Dunaliella tertiolecta for bio-oil in sub/supercritical ethanol-water. Bioresour. Technol. 2012, 124, 190-198. [CrossRef]

19. Yang, L.; Li, Y.; Savage, P.E. Near- and supercritical ethanol treatment of biocrude from hydrothermal liquefaction of microalgae. Bioresour. Technol. 2016, 211, 779-782. [CrossRef]

20. Xu, D.; Lin, G.; Guo, S.; Wang, S.; Guo, Y.; Jing, Z. Catalytic hydrothermal liquefaction of algae and upgrading of biocrude: A critical review. Renew. Sustain. Energy Rev. 2018, 97, 103-118. [CrossRef]

21. Jena, U.; Das, K.C.; Kastner, J.R. Comparison of the effects of Na2CO3, Ca3(PO4)2, and NiO catalysts on the thermochemical liquefaction of microalga Spirulina platensis. Appl. Energy 2012, 98, 368-375. [CrossRef]

22. Yu, G.; Zhang, Y.; Guo, B.; Funk, T.; Schideman, L. Nutrient Flows and Quality of Bio-crude Oil Produced via Catalytic Hydrothermal Liquefaction of Low-Lipid Microalgae. Bioenergy Res. 2014, 7, 1317-1328. [CrossRef]

23. Ross, A.B.; Biller, P.; Kubacki, M.L.; Li, H.; Lea-Langton, A.; Jones, J.M. Hydrothermal processing of microalgae using alkali and organic acids. Fuel 2010, 89, 2234-2243. [CrossRef]

24. Yang, W.; Li, X.; Liu, S.; Feng, L. Direct hydrothermal liquefaction of undried macroalgae Enteromorpha prolifera using acid catalysts. Energy Convers. Manag. 2014, 87, 938-945. [CrossRef]

25. Chen, Y.; Mu, R.; Yang, M.; Fang, L.; Wu, Y.; Wu, K.; Liu, Y.; Gong, J. Catalytic hydrothermal liquefaction for bio-oil production over CNTs supported metal catalysts. Chem. Eng. Sci. 2017, 161, 299-307. [CrossRef]

26. Robin, T.; Jones, J.M.; Ross, A.B. Catalytic hydrothermal processing of lipids using metal doped zeolites. Biomass Bioenergy 2017, 98, 26-36. [CrossRef]

27. Duan, P.; Savage, P.E. Hydrothermal Liquefaction of a Microalga with Heterogeneous Catalysts. Ind. Eng. Chem. Res. 2011, 50, 52-61. [CrossRef]

28. Chang, F.; Zhou, Q.; Pan, H.; Liu, X.-F.; Zhang, H.; Xue, W.; Yang, S. Solid Mixed-Metal-Oxide Catalysts for Biodiesel Production: A Review. Energy Technol. 2014, 2, 865-873. [CrossRef]

29. Gryglewicz, S. Rapeseed oil methyl esters preparation using heterogeneous catalysts. Bioresour. Technol. 1999, 70, 249-253. [CrossRef]

30. Granados, M.L.; Poves, M.D.Z.; Alonso, D.M.; Mariscal, R.; Galisteo, F.C.; Moreno-Tost, R.; Santamaría, J.; Fierro, J.L.G. Biodiesel from sunflower oil by using activated calcium oxide. Appl. Catal. B Environ. 2007, 73, 317-326. [CrossRef]

31. Kouzu, M.; Hidaka, J.S. Transesterification of vegetable oil into biodiesel catalyzed by CaO: A review. Fuel 2012, 93, 1-12. [CrossRef]

32. Dossin, T.F.; Reyniers, M.-F.; Marin, G.B. Kinetics of heterogeneously MgO-catalyzed transesterification. Appl. Catal. B Environ. 2006, 62, 35-45. [CrossRef]

33. Refaat, A.A. Biodiesel production using solid metal oxide catalysts. Int. J. Environ. Sci. Technol. 2011, 8, 203-221. [CrossRef]

34. Mendoza, A.; Vicente, G.; Bautista, L.F.; Morales, V. Opportunities for Nannochloropsis gaditana biomass through the isolation of its components and biodiesel production. Green Process. Synth. 2015, 4, 97-102. [CrossRef]

35. Li, H.; Liu, Z.; Zhang, Y.; Li, B.; Lu, H.; Duan, N.; Liu, M.; Zhu, Z.; Si, B. Conversion efficiency and oil quality of low-lipid high-protein and high-lipid low-protein microalgae via hydrothermal liquefaction. Bioresour. Technol. 2014, 154, 322-329. [CrossRef]

36. López Barreiro, D.; Samorì, C.; Terranella, G.; Hornung, U.; Kruse, A.; Prins, W. Assessing microalgae biorefinery routes for the production of biofuels via hydrothermal liquefaction. Bioresour. Technol. 2014, 174, 256-265. [CrossRef]

37. Shi, W.; Li, S.; Jin, H.; Zhao, Y.; Yu, W. The hydrothermal liquefaction of rice husk to bio-crude using metallic oxide catalysts. Energy Sources Part A Recover. Util. Environ. Eff. 2013, 35, 2149-2155. [CrossRef]

38. Yim, S.C.; Quitain, A.T.; Yusup, S.; Sasaki, M.; Uemura, Y.; Kida, T. Metal oxide-catalyzed hydrothermal liquefaction of Malaysian oil palm biomass to bio-oil under supercritical condition. J. Supercrit. Fluids 2016, 120, 384-394. [CrossRef]

39. Valdez, P.J.; Tocco, V.J.; Savage, P.E. A general kinetic model for the hydrothermal liquefaction of microalgae. Bioresour. Technol. 2014, 163, 123-127. [CrossRef] 
40. Wang, W.; Xu, Y.; Wang, X.; Zhang, B.; Tian, W.; Zhang, J. Hydrothermal liquefaction of microalgae over transition metal supported TiO2 catalyst. Bioresour. Technol. 2018, 250, 474-480. [CrossRef]

41. Pedersen, T.H.; Jensen, C.U.; Sandström, L.; Rosendahl, L.A. Full characterization of compounds obtained from fractional distillation and upgrading of a HTL biocrude. Appl. Energy 2017, 202, 408-419. [CrossRef]

42. Karmakar, R.; Kundu, K.; Rajor, A. Fuel properties and emission characteristics of biodiesel produced from unused algae grown in India. Pet. Sci. 2018, 15, 385-395. [CrossRef]

43. Ahmed, I. Oxygenated Diesel: Emissions and Performance Characteristics of Ethanol-Diesel Blends in CI Engines; SAE Technical Paper; SAE International: Warrendale, PA, USA, 2001.

44. Kurtz, E.M.; Kuhel, D.; Anderson, J.E.; Mueller, S.A. A Comparison of Combustion and Emissions of Diesel Fuels and Oxygenated Fuels in a Modern DI Diesel Engine. SAE Int. J. Fuels Lubr. 2012, 5, 1199-1215. [CrossRef]

45. Duan, P.; Wang, B.; Xu, Y. Catalytic hydrothermal upgrading of crude bio-oils produced from different thermo-chemical conversion routes of microalgae. Bioresour. Technol. 2015, 186, 58-66. [CrossRef] [PubMed]

46. Garcia Alba, L.; Torri, C.; Samorì, C.; Van Der Spek, J.; Fabbri, D.; Kersten, S.R.A.; Brilman, D.W.F. Hydrothermal treatment (HTT) of microalgae: Evaluation of the process as conversion method in an algae biorefinery concept. Energy Fuels 2012, 26, 642-657. [CrossRef]

(C) 2019 by the authors. Licensee MDPI, Basel, Switzerland. This article is an open access article distributed under the terms and conditions of the Creative Commons Attribution (CC BY) license (http://creativecommons.org/licenses/by/4.0/). 